Article

\title{
Human scFvs That Counteract Bioactivities of Staphylococcus aureus TSST-1
}

\author{
Thunchanok Rukkawattanakul ${ }^{1,2}$, Nitat Sookrung ${ }^{2,3}$, Watee Seesuay ${ }^{2}$, Nattawat Onlamoon ${ }^{3}$, \\ Pornphan Diraphat ${ }^{4}$, Wanpen Chaicumpa ${ }^{2}$ and Nitaya Indrawattana ${ }^{5, *}$ \\ 1 Graduate Program in Immunology, Department of Immunology, Faculty of Medicine Siriraj Hospital, \\ Mahidol University, Bangkok 10700, Thailand; ruk.thunchanok@gmail.com \\ 2 Center of Research Excellence on Therapeutic Proteins and Antibody Engineering, Department of \\ Parasitology, Faculty of Medicine Siriraj Hospital, Mahidol University, Bangkok 10700, Thailand; \\ nitat.soo@mahidol.ac.th (N.S.); watee.see@gmail.com (W.S.); wanpen.cha@mahidol.ac.th (W.C.) \\ 3 Department of Research and Development, Faculty of Medicine Siriraj Hospital, Mahidol University, \\ Bangkok 10700, Thailand; nattawat.onl@mahidol.ac.th (N.O.) \\ 4 Department of Microbiology, Faculty of Public Health, Mahidol University, Bangkok 10400, Thailand; \\ pornphan.dir@mahidol.ac.th \\ 5 Department of Microbiology and Immunology, Faculty of Tropical Medicine, Mahidol University, \\ Bangkok 10400, Thailand \\ * Correspondence: nitaya.ind@mahidol.ac.th; Tel.: +66-2-354-9100 (ext. 1598); Fax: +66-2-643-5583
}

Academic Editor: Andreas Rummel

Received: 7 November 2016; Accepted: 9 February 2017; Published: 17 February 2017

\begin{abstract}
Some Staphylococcus aureus isolates produced toxic shock syndrome toxin-1 (TSST-1) which is a pyrogenic toxin superantigen (PTSAg). The toxin activates a large fraction of peripheral blood $\mathrm{T}$ lymphocytes causing the cells to proliferate and release massive amounts of pro-inflammatory cytokines leading to a life-threatening multisystem disorder: toxic shock syndrome (TSS). PTSAg-mediated-T cell stimulation circumvents the conventional antigenic peptide presentation to T cell receptor (TCR) by the antigen-presenting cell (APC). Instead, intact PTSAg binds directly to MHC-II molecule outside peptide binding cleft and simultaneously cross-links TCR-V $\beta$ region. Currently, there is neither specific TSS treatment nor drug that directly inactivates TSST-1. In this study, human single chain antibodies (HuscFvs) that bound to and neutralized bioactivities of the TSST-1 were generated using phage display technology. Three E. coli clones transfected with TSST-1-bound phages fished-out from the human ScFv library using recombinant TSST-1 as bait expressed TSST-1-bound-HuscFvs that inhibited the TSST-1-mediated $\mathrm{T}$ cell activation and pro-inflammatory cytokine gene expressions and productions.Computerized simulation, verified by mutations of the residues of $\mathrm{HuscFv}$ complementarity determining regions (CDRs),predicted to involve in target binding indicated that the HuscFvs formed interface contact with the toxin residues important for immunopathogenesis. The HuscFvs have high potential for future therapeutic application.
\end{abstract}

Keywords: direct acting anti-TSST-1; human scFv; Staphylococcus aureus; superantigen; Toxic shock syndrome (TSS)

\section{Introduction}

Superantigens (SAgs) are proteins produced by some bacterial and viral strains that mediate $\mathrm{T}$ cell activation by bypassing the conventional peptide-MHC-II presentation to T cell receptor (TCR) [1]. Instead, intact (unprocessed) SAgs bind directly to MHC-II molecules on the antigen presenting cells (APC)and simultaneously cross-link TCR-V $\beta$ domains shared by about $5 \%-20 \%$ of circulating $C D 4^{+}$ 
and $\mathrm{CD} 8^{+} \mathrm{T}$ lymphocytes [1,2]. T cell stimulation by SAgs is Lck pathway-independent [3], initiated at the $\mathrm{G} \alpha 11$ (a membrane raft-enriched heterotrimeric G-protein) that stimulates PLC $\beta$ and PKC to activate mitogen-activated protein kinases (ERKs) causing nuclear translocation of NF-AT and NF- $\mathrm{KB}$ and cytokine gene expressions [3]. Massive amounts of cytokines including IL-1 $\beta$, IL-2, IL-6,TNF $\alpha$ and IFN $\gamma$ are released from the activated cells into the circulation [1] leading to high fever, rash, skin desquamation (peeling), plasma leakage, obstinate hypotension, and life-threatening multisystem organ failure called toxic shock syndrome (TSS) [2,4]. SAgs potentiate host sensitivity to bacterial endotoxin resulting in TNF $\alpha$-mediated capillary leakage which is the major contributor of the TSS [5,6].

Staphylococcus aureus secretes several pyrogenic toxin superantigens (PTSAgs) including toxic shock syndrome toxin-1 (TSST-1) and many enterotoxins [1,7]. TSST-1 is a prototype of group I PTSAgs responsible for most cases of menstrually-related-TSS and a large proportion of non-menstrual cases, i.e., patients with surgical wound and cutaneous infections, osteomyelitis, arthritis, burns, post-partum infection, and barrier contraceptive users [8,9]. Although PTSAgs share nearly identical tertiary structure, their primary sequences are diverse (only 20\%-30\% identity) and the way they interact with the host receptors (MHC-II and TCR) are different [10-16]. For examples, S. aureus TSST-1 occupies almost one-half of the HLA-DR1 and contact with $\alpha$-helices of the MHC-II and the bound peptide while S. aureus enterotoxin B binds to only one edge of the peptide binding cleft of the DR1 [10]. TSST-1 is encoded by $t s t \mathrm{H}$ gene in the $\mathrm{S}$. aureus mobile genetic element [17]. TSST-1 structure and regions that interacted with MHC-II and TCR have been investigated extensively [10,18-20]. Mature toxin (194 residues; $\sim 22 \mathrm{kDa}$ ) is monomeric in solution and comprises two tightly packed-distinct domains $[18,20]$. The $\mathrm{N}$-terminal domain (small domain B) acquires $\alpha$-helix configuration $(\alpha 1$; residues $1-17)$ that is surrounded by five $\beta$-strands ( $\beta 1-\beta 5$; residues $18-89$ ). The $C$-terminal domain (large domain $A$ ) is connected to the $\mathrm{N}$-domain and contains a long $\alpha$-helix ( $\alpha 2$ or the toxin backbone; residues $125-141$ ) packed against five $\beta$ strands; residues $90-194)$ that form a $\beta$-grasp motif [18-20]. N-terminal domain of TSST-1 binds MHC-II, while C-terminal domainis implicated in binding to TCR-V $\beta[10,16,18,21]$.

TSS management includes supportive and symptomatic treatment. Antimicrobials and surgical debridement to remove the toxin-producing microorganisms are important. Maintaining blood pressure by fluid therapy is necessary [22,23]. Intravenous immunoglobulin (IVIG) confers some benefit to the patients [24].Murine monoclonal antibodies that neutralized endotoxin prevented rabbits from lethal TSS and endotoxin challenge [6]. Symptom severity of TSS was mitigated in a rabbit model after giving a mouse monoclonal antibody that neutralized TSST-1 activities [25]. Rabbit polyclonal antisera against wild type and TSST-1 mutants (G31R and H135A which affected MHC-II and TCR bindings) protected rabbits even when given late in the course of the TSST-1 challenge [26]. In this study, human monoclonal single chain antibodies (HuscFvs) that bound to functionally important residues of TSST-1 were produced by phage display technology. HuscFvs of three phage-transformed Escherichia coli clones inhibited TSST-1 mitogenicity (activation of T cell proliferation) and pyrogenicity (induction of pro-inflammatory cytokine gene expressions and the cytokine secretions). The human scFvs have high potential for testing further as a safe, direct acting anti-TSST-1 remedy.

\section{Results and Discussion}

\subsection{Recombinant TSST-1 and Activities}

Recombinant pET21a $\mathrm{a}^{+}$with TSST-1 gene insert was synthesized (GenScript) and used to transform $\mathrm{NiCo} 21$ (DE3) E. coli. Amplicon of the gene is shown in Figure 1A. From $1 \mathrm{~L}$ culture of the transformed E. coli grown under $1 \mathrm{mM}$ isopropyl $\beta$-D-1-thiogalactopyranoside (IPTG) induction, 1.46 grams of purified recombinant protein was obtained. The purified preparation revealed only one protein band in SDS-PAGE and protein staining (lane 1, left panel of Figure 1B) and Western blotting (lane 1, right panel of Figure 1B). The LPS content of the purified preparation was 0.15 endotoxin unit (EU)/microgram. One endotoxin unit was approximately $0.1-0.2 \mathrm{ng}$ [27]. Mass spectrometry verified that the recombinant protein was TSST-1 (Table 1). Figure S1A shows codon-optimized nucleotide sequence of the TSST-1 of 
this study. BamHI and HindIII restriction sites were placed at the $5^{\prime}$ and $3^{\prime}$ ends of the gene sequence, respectively; a stop codon of the TSST- 1 gene was removed from the $3^{\prime}$ end upstream of the HindIII site. The deduced amino acid sequence, which has $100 \%$ amino acid identity to the TSST- 1 of the database (accession J02615), is shown in Figure S1B.
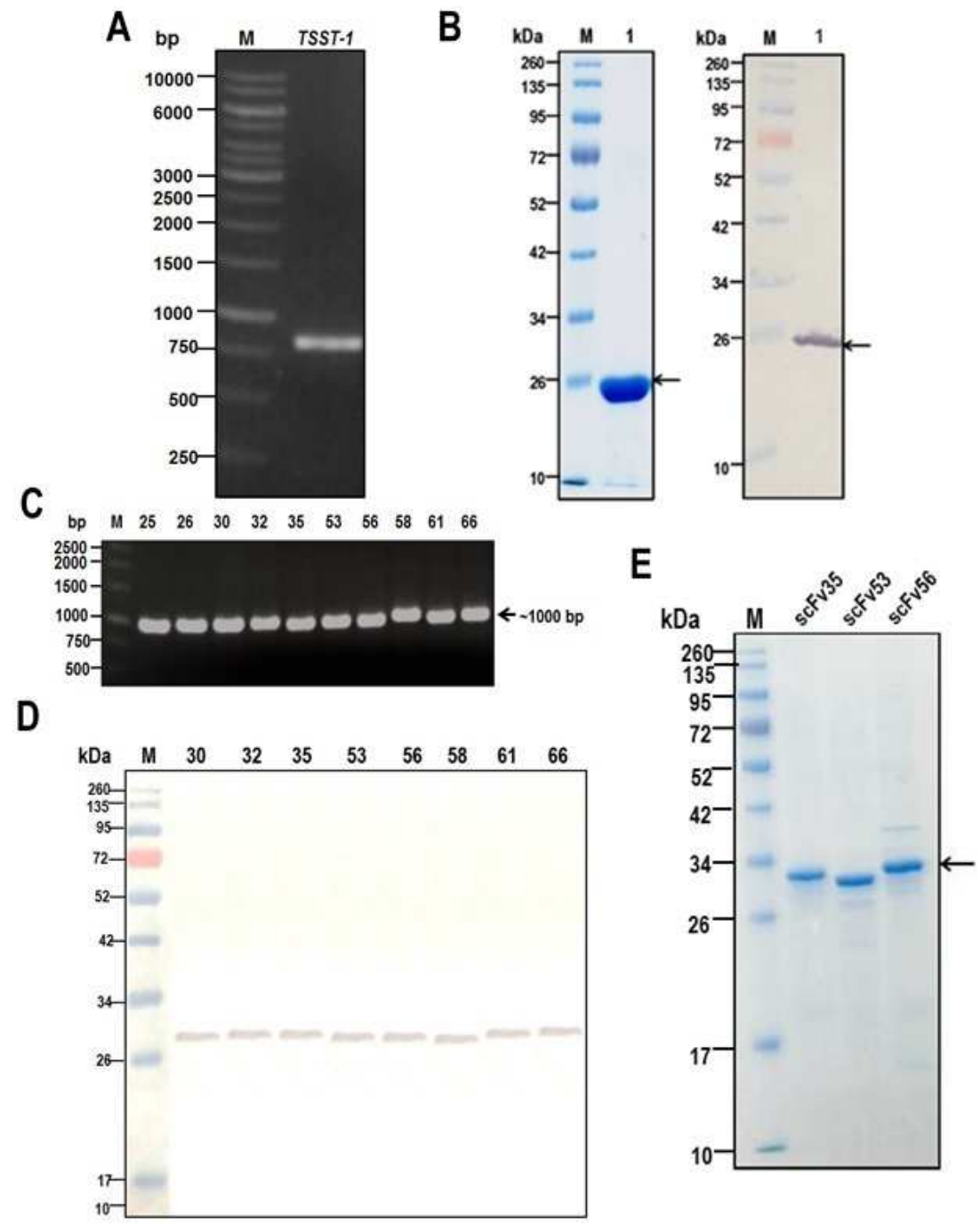

Figure 1. (A) Amplicon of TSST-1 gene. (B) Stained-SDS-PAGE-separated-rTSST-1 (1 $\mu$ g per lane) (lane 1 of left panel)and Western blot pattern (lane 1 of right panel). In the Western blotting, mouse monoclonal anti- $6 \times$ His (AbDSerotec) at 1:3000 was used as the primary antibody; goat-anti-mouse isotype-alkaline phosphatase conjugate (Southern Biotech) at 1:3000 as secondary antibody and BCIP/NBT substrate (KPL). (C) Amplicons of huscfus ( 1000 bp) from 10 phage-transformed HB2151 E. coli clones. (D) Binding of HuscFvs in lysates of 8 HB2151 E. coli clones to SDS-PAGE-separated-rTSST-1 (1 $\mu \mathrm{g}$ per lane). (E) SDS-PAGE-separated- purified and refolded HuscFv35, HuscFv53, and HuscFv56 from transformed NiCo21 (DE3) E. coli. $\mathrm{M}$ in (A,C) DNA ladders in base-pairs (bp); $\mathrm{M}$ in (B,D,E) protein markers in $\mathrm{kDa}$.

The rTSST- 1 at 10, 100, and $1000 \mathrm{ng} / \mathrm{mL}$ activated T cells to express CD69 (T cell activation marker) by $5.2 \%, 6.3 \%$, and $7.2 \%$, respectively, compared with $0.6 \%$ of the negative control (cells in medium alone) and $24.8 \%$ of the cells stimulated by $1000 \mathrm{ng} / \mathrm{mL}$ PHA (pan T cell mitogen) which served as positive control (Figure 2A). At $72 \mathrm{~h}$ after exposure to rTSST-1 (10, 100, and $1000 \mathrm{ng} / \mathrm{mL}$ ) and PHA $(1000 \mathrm{ng} / \mathrm{mL})$, the percentages of proliferated cells were $5.1 \%, 6.2 \%, 7.5 \%$, and $26.8 \%$, respectively, compared with $0.5 \%$ of the cells in medium alone (Figure $2 \mathrm{~B}$ ). 
Table 1. LC-MS/MS Mascot results of peptides generated from recombinant TSST-1 of this study with $30 \%$ sequence coverage.

\begin{tabular}{|c|c|c|c|c|c|}
\hline Proteins & $\begin{array}{l}\text { Orthologous } \\
\text { Protein }\end{array}$ & $\begin{array}{l}\text { Accession } \\
\text { No. }\end{array}$ & $\begin{array}{c}\text { Number of } \\
\text { Matched Peptides }\end{array}$ & Score & Matched Peptide Sequence (Score) \\
\hline TSST-1 & $\begin{array}{l}\text { Toxic shock } \\
\text { syndrome toxin-1 } \\
\text { of S. aureus }\end{array}$ & Gi 136457 & 9 & 239 & $\begin{array}{c}\text { DSPLKYGPK (44) } \\
\text { LPTPIELPLKVK (38) } \\
\text { HQLTQIHGLYR (36) } \\
\text { ITMNDGSTYQSDLSK (91) } \\
\text { ITMNDGSTYQSDLSK (35) } \\
\text { ITMNDGSTYQSDLSK (28) } \\
\text { ITMNDGSTYQSDLSK (28) } \\
\text { NTDGSISLIIFPSPYYSPAFTKGEK (32) } \\
\text { NTDGSISLIIFPSPYYSPAFTKGEK (23) }\end{array}$ \\
\hline
\end{tabular}

A

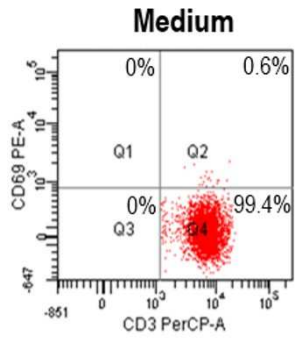

TSST-1 $1000 \mathrm{ng} / \mathrm{mL}$

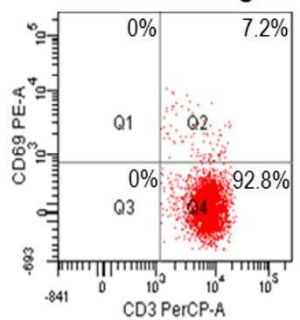

B



TSST-1 $1000 \mathrm{ng} / \mathrm{mL}$

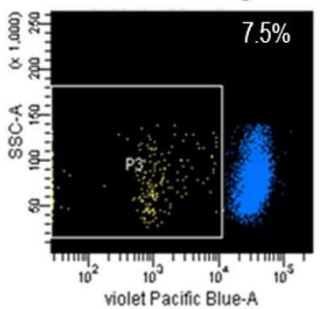

TSST-1 $10 \mathrm{ng} / \mathrm{mL}$

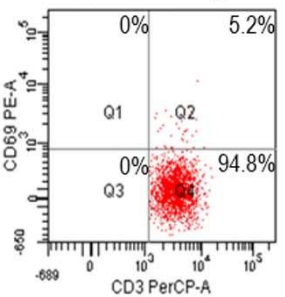

PHA

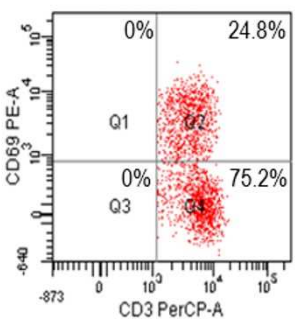

TSST-1 $10 \mathrm{ng} / \mathrm{mL}$

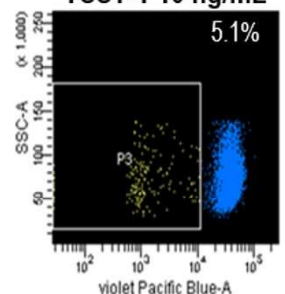

TSST-1 $100 \mathrm{ng} / \mathrm{mL}$

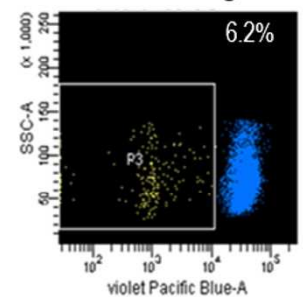

PHA

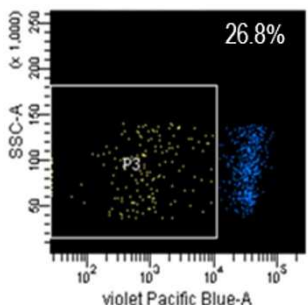

TSST-1 $100 \mathrm{ng} / \mathrm{mL}$

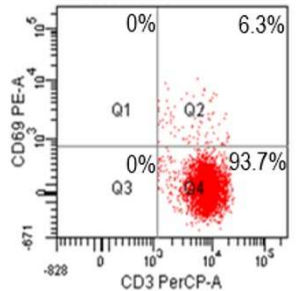


The rTSST-1 at 10, 100, and $1000 \mathrm{ng} / \mathrm{mL}$ were tested for pyrogenicity (ability to induce pro-inflammatory cytokine gene expressions in stimulated cells). Figure 3 shows fold-increase of IL-1 $\beta$, IL-6, and TNF $\alpha$ gene expressions, respectively, in the human PBMCs after stimulation with rTSST-1 and PHA (positive control) in comparison with non-stimulated cells. Pyrogenicity of the rTSST-1 was not concentration dependent which was conformed to the results reported previously [28].
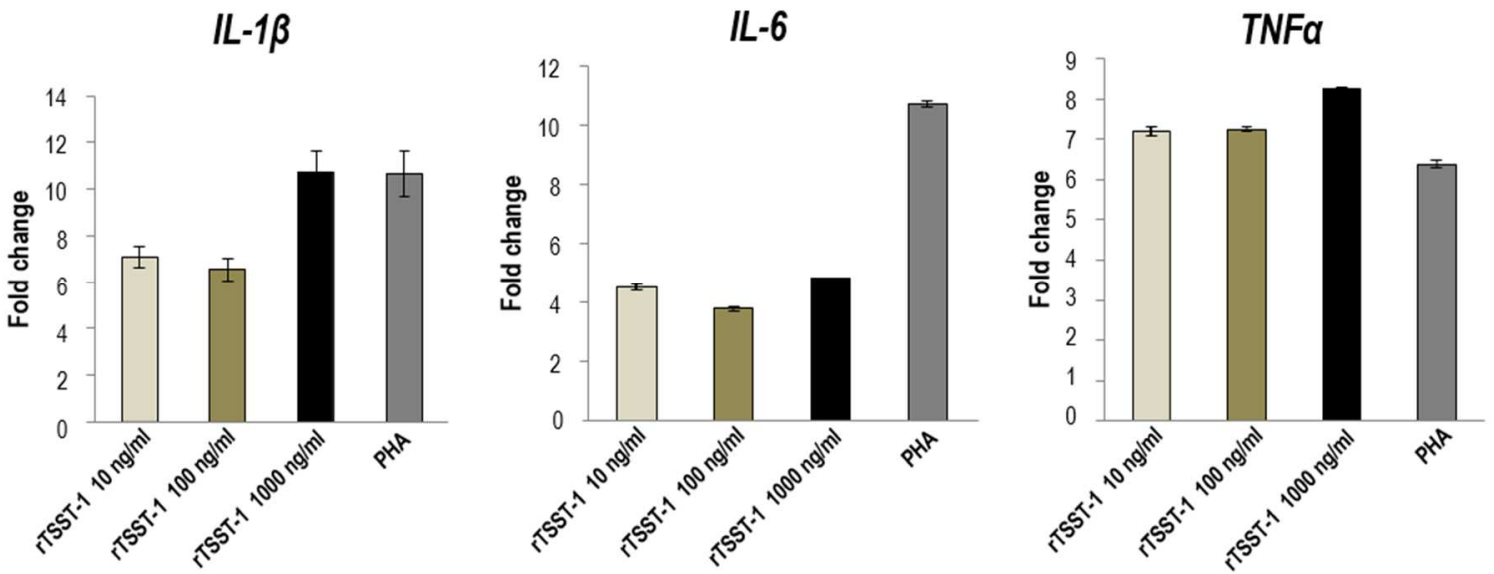

Figure 3. Pyrogenicity of the rTSST-1 (ability to induce stimulated cells to express pro-inflammatory cytokine genes). Fold increase of $I L-1 \beta, I L-6$, and TNF $\alpha$ expressions in the human PBMCs after stimulation with rTSST-1 at 10, 100, and $1000 \mathrm{ng} / \mathrm{mL}$ and $1000 \mathrm{ng} / \mathrm{mL}$ PHA (positive control) in relation to non-stimulated cells (negative control).

To exclude the effect of contaminated LPS in the TSST-1 preparation, an experiment in which 1 $\mu \mathrm{g} / \mathrm{mL}$ of LPS (Sigma-Aldrich, St. Louis, MO, USA) was used to stimulate the PBMCs was performed. It was found that the LPS induced only $28 \%$ of the cell proliferation compared to $100 \%$ stimulation by $1000 \mathrm{ng} / \mathrm{mL}$ of TSST-1 (Figure S2). Overall results indicated that the bacterially derived-rTSST-1 acquired the inherent activities of the native counterpart. Thus, the active protein was used further.

\subsection{Production of HuscFvs}

Ten colonies of the HB2151 E. coli transfected with rTSST-1-bound phages derived from the human scFv phage display library by means of phage bio-panning using the rTSST-1 as bait (see Materials and Methods) revealed amplicons of HuscFv coding genes (huscfv; 1000 bp) (Figure 1C). Only eight clones produced soluble HuscFvs that bound to SDS-PAGE-separated-rTSST-1 (Figure 1D). Even though the HuscFvs bound to the rTSST-1 which was prepared in buffer containing reducing agents (SDS and mercaptoethanol) in the Western blotting, conclusion cannot be made at this stage that the rTSST-1 epitopes are linear sequences [29]. After nucleotide sequencing, three clones (nos. 35, 53, and 56) showed complete HuscFv sequences, i.e., contiguous sequence coding for $\mathrm{IgVH}$, peptide linker $\left(\mathrm{Gly}_{4} \mathrm{Ser}_{1}\right)_{3}$, and IgVL. Therefore, huscfos of these three clones were subcloned into pLATE52 vector and the recombinant vector was used to transform NiCo21 (DE3) E. coli for large scale production of the antibodies. Inclusion bodies were purified from homogenates of the E. coli grown under IPTG induction condition and the HuscFvs were refolded. Figure 1E shows SDS-PAGE-separated purified and refolded HuscFvs. The refolded antibodies retained their binding specificity to the TSST-1 coated on the ELISA well surface with and without BSA as determined by indirect ELISA (Figure S3); indicating that the antibodies were refolded properly. The HuscFvs also bound to S. aureus enterotoxin A (SEA) (Figure S3). 


\subsection{Presumptive Residues and Regions of TSST-1 Bound by the HuscFvs}

TSST-1 3D structure (PDB 2IJO) and modeled HuscFvs (Table S1) were subjected to intermolecular docking. Interactive modes: salt-bridge, hydrogen, hydrophobic, and van der Waals, were selected from molecular dynamic results. The lowest energy scores for TSST-1 complexed with HuscFv35, HuscFv53, and HuscFv56 were $-304 \pm 75.4,-243.3 \pm 23.7$, and $-371.6 \pm 15.3 \mathrm{kcal} / \mathrm{mol}$, respectively. Tables 2-4, Figure S4A-C, and Figure S5 show TSST-1 residues and motives that were predicted to form contact interface with HuscFv35, HuscFv53, and HuscFv56. Epitopes of the HuscFv35 and HuscFv56 tend to be conformational, i.e., formed by residues in the separated portions of the TSST-1 molecule that are spatially juxtapose upon the active protein folding, while residues that formed predicted HuscFv53 epitope located mainly between $\beta 4$ and $\beta 5$ of the TSST- 1 N-terminal domain,suggesting that the epitope might be linear (Figure S5).

HuscFv35 was predicted to interact with TSST-1 at S1, D4, I6, K7, W12 and S15 of $\alpha 1$-helix, G16 before $\beta 1$-strand, K67, R68, K71, S72, and Q73 of $\beta 4$-strand, and $\beta 5$ Y80 (Table 2). Rabbit immune sera predominantly reacted with residues 1-15 of the TSST-1 N-terminal domain was shown previously to neutralize TSST-1 mitogenicity [30]. Blocking of $\alpha 1$-helix impaired interaction between TSST-1 and MHC-II molecules [30]. S15-G16 peptide bond has been shown to play a role in modulating TSST-1 mitogenicity [31]. A side chain on residue 16 geometrically stabilizes the wild type TSST-1 [32]. G16 (located in the last turn of $\alpha 1$ ) and S15 were affected when H135 was mutated to alanine and this impaired TSST-1-TCR interaction [30]. Y80W TSST-1 had reduced mitogenicity in a rabbit model [33]. TSST-1 with R68A and S72A mutations failed to activate T cells carrying V 32 TCR [34]. Functions of K67, K71, and Q73 are elusive. Results of computerized simulation suggested that HuscFv35 should be able to reduce TSST-1 mitogenicity by interfering with TSST-1 binding to TCR-v $\beta$ and cause reduction of TSST-1-mediated cellular cytokine release by interfering with several important residues of the toxin.

Table 2. TSST-1 residues and motives predicted to be bound by residues and domains ofHuscFv35. After residues labeled in red were mutated to alanines, the HuscFv35 lost ability to suppress TSST-1 mitogenicity and pyrogenicity.

\begin{tabular}{|c|c|c|c|c|}
\hline \multicolumn{2}{|c|}{ TSST-1 } & \multicolumn{2}{|c|}{ HuscFv35 } & \multirow{2}{*}{ Intermolecular Bond } \\
\hline Residue & Motif & Residue(s) & Domain & \\
\hline S1 & $\alpha 1$-helix & T165 & VL-CDR1 & Van de Waals \\
\hline D4 & Before $\alpha 1$-helix & T165 & VL-CDR1 & Van de Waals \\
\hline $\mathrm{D} 4$ & Before $\alpha 1$-helix & N166 & VL-CDR1 & H-bond \\
\hline I6 & $\alpha 1$-helix & N166 & VL-CDR1 & H-bond \\
\hline K7 & $\alpha 1$-helix & Y168 & VL-CDR1 & Water bridge \\
\hline K7 & $\alpha 1$-helix & Y227 & VL-CDR3 & H-bond \\
\hline K7 & $\alpha 1$-helix & D228 & VL-CDR3 & H-bond \\
\hline D8 & $\alpha 1$-helix & Y103 & VL-CDR3 & $\mathrm{OH}-\pi$ \\
\hline D8 & Before $\alpha 1$-helix & N166 & VL-CDR1 & Van de Waals \\
\hline W12 & $\alpha 1$-helix & L102 & VH-CDR3 & $\mathrm{CH}-\pi$ \\
\hline $\mathrm{S} 15$ & $\alpha 1$-helix & Q101 & VL-CDR3 & H-bond \\
\hline G16 & Before $\beta 1$-strand & Q101 & VH-CDR3 & Hydrophobic \\
\hline K67 & $\beta 4$-strand & Q101 & VH-CDR3 & Water bridge \\
\hline R68 & $\beta 4$-strand & D31 & VH-CDR1 & $\mathrm{H}$-bond \\
\hline R68 & $\beta 4$-strand & H100 & VH-CDR3 & $\mathrm{CH}-\pi$ \\
\hline R68 & $\beta 4$-strand & Q101 & VH-CDR3 & Van de Waals \\
\hline K71 & $\beta 4$-strand & H100 & VH-CDR3 & $\mathrm{CH}-\pi$ \\
\hline K71 & $\beta 4$-strand & D108 & VH-CDR3 & H-bond \\
\hline K71 & $\beta 4$-strand & Y185 & VL-FR2 & H-bond \\
\hline S72 & $\beta 4$-strand & H100 & VH-CDR3 & H-bond \\
\hline Q73 & $\beta 4$-strand & T192 & VL-FR3 & $\mathrm{H}$ bond \\
\hline Y80 & $\beta 5$-strand & Y27 & VH-FR1 & $\mathrm{H}$ bond \\
\hline Y80 & $\beta 5$-strand & D31 & VH-CDR1 & $\mathrm{OH}-\pi$ \\
\hline
\end{tabular}


By the in silico docking, HuscFv53 contacted with D18 (before $\beta 1$-strand), D39 (before $\beta 3$-strand), and R68; K71 and H74 ( $\beta 4$-strand); S76 and E77 (before $\beta 5$-strand); and Y80 ( $\beta 5$-strand) of the TSST-1 N-terminal domain (Table 3, Figures S4B and S5). R68A rendered TSST-1 inability to bind to the HLA-DR2 [34]. Y80W TSST-1 had reduced mitogenicity in a rabbit model [35]. Functions of other residues predicted to form contact interface with the HuscFv53 are unknown. Based on the computerized results, the HuscFv53 should not be as effective as the HuscFv35 in mitigation/amelioration of the TSST-1 bioactivities.

HuscFv56 was predicted to interact with TSST-1 K7, L10, D11 and S15 of $\alpha 1$-helix; S17 and D18 before $\beta 1$-strand; T19 and F20 of $\beta 1$-strand; D39 before $\beta 3$-strand; N65, R68, K71, S72 and H74 of $\beta 4$-strand; $\mathrm{Y} 80$ of $\beta 5$-strand; K114, Y115, and P117 before $\beta 8$-strand; K118 and F119 of $\beta 8$-strand; E132, H135, T138, Q139 and I140 of $\alpha 2$-helix; and R145 before $\beta$-strand (Table 4, Figures S4C and S5). Importance of TSST-1 R68 and S72 on the TCR-V $\beta$ binding and N-terminal residues 1-15 (which include K7, D11, and S15) and Y80 on T cell mitogenicity has been mentioned above. H135 and Q139 on the $\alpha 2$-helix have been shown to be important for the TSST-1 superantigenicity [18,32,35-37]. Previous data indicated that H135A TSST- 1 mutant possessed only $5 \%-10 \%$ mitogenicity of the wild type [35]. H135 and Q139 are individually critical for functional activity and direct interaction of TSST- 1 with TCR-v $\beta$ [37]. TSST- 1 with H135 mutated to alanine had abolished capacity to induce TNF- $\alpha$ and IL-6 mRNA expressions and protein production [35]. Y115 is a pronounced inducer of IL-6 and TNF $\alpha$ as well as IL-8 [36]. Y115A mutant of TSST-1 had much reduced mitogenicity on T cells and did not express significant toxicity in the rabbit model of TSS [35]. Because the HuscFv56 formed interface contact with several important TSST-1 residues, this antibody should be able to neutralize the TSST-1 activities.

Table 3. TSST-1 residues and motives predicted to be bound by residues and domains of HuscFv53. After residues labeled in red were mutated to alanines, the HuscFv53 lost ability to suppress TSST-1 mitogenicity and pyrogenicity.

\begin{tabular}{|c|c|c|c|c|}
\hline \multicolumn{2}{|c|}{ TSST-1 } & \multicolumn{2}{|c|}{ HuscFv53 } & \multirow{2}{*}{ Intermolecular Bond } \\
\hline Residue & Motif & Residue(s) & Domain & \\
\hline D18 & Before $\beta 1$-strand & R31 & VH-CDR1 & H-bond \\
\hline D39 & Before $\beta 3$-strand & R31 & VH-CDR1 & H-bond \\
\hline R68 & $\beta 4$-strand & T52 & VH-CDR2 & Van de Waals \\
\hline R68 & $\beta 4$-strand & D57 & VH-CDR2 & H-bond \\
\hline K71 & $\beta 4$-strand & W33 & VH-CDR1 & $\mathrm{NH}-\pi$ \\
\hline K71 & $\beta 4$-strand & $\mathrm{T} 52$ & VH-CDR2 & H-bond \\
\hline K71 & $\beta 4$-strand & D57 & VH-CDR2 & H-bond \\
\hline Q73 & $\beta 4$-strand & W33 & VH-CDR1 & Van de Waals \\
\hline Q73 & $\beta 4$-strand & W230 & VL-CDR3 & Van de Waals \\
\hline $\mathrm{H} 74$ & $\beta 4$-strand & W33 & VH-CDR3 & $\pi$-stacking \\
\hline $\mathrm{H} 74$ & $\beta 4$-strand & R100 & VH-CDR3 & $\mathrm{NH}-\pi$ \\
\hline $\mathrm{H} 74$ & $\beta 4$-strand & F101 & VL-CDR1 & $\pi$-stacking \\
\hline S76 & Before $\beta 5$-strand & D166 & VL-CDR1 & $\mathrm{H}$ bond \\
\hline S76 & Before $\beta 5$-strand & Y168 & VL-CDR1 & $\mathrm{H}$ bond \\
\hline S76 & Before $\beta 5$-strand & K186 & VL-CDR2 & $\mathrm{H}$ bond \\
\hline E77 & Before $\beta 5$-strand & K186 & VL-CDR2 & Water bridge \\
\hline Y80 & $\beta 5$-strand & W33 & VH-CDR1 & H-bond \\
\hline Y80 & $\beta 5$-strand & R100 & VH-CDR3 & $\mathrm{NH}-\pi$ \\
\hline
\end{tabular}


Table 4. TSST-1 residues and motives predicted to be bound by residues and domains ofHuscFv56. After residues labeled in red were mutated to alanines, the HuscFv56 lost ability to suppress TSST-1 mitogenicity and pyrogenicity.

\begin{tabular}{|c|c|c|c|c|}
\hline \multicolumn{2}{|c|}{ TSST-1 } & \multicolumn{2}{|c|}{ HuscFv56 } & \multirow{2}{*}{ Intermolecular Bond } \\
\hline Residue & Motif & Residue(s) & Domain & \\
\hline K7 & $\alpha 1$-helix & S162 & VL-CDR1 & H-bond \\
\hline K7 & $\alpha 1$-helix & I163 & VL-CDR1 & Van der Waals \\
\hline L10 & $\alpha 1$-helix & I163 & VL-CDR1 & Hydrophobic \\
\hline D11 & $\alpha 1$-helix & I163 & VL-CDR1 & Van de Waals \\
\hline D11 & $\alpha 1$-helix & R164 & VL-CDR1 & H-bond \\
\hline D11 & $\alpha 1$-helix & Y165 & VL-CDR1 & $\mathrm{OH}-\pi$ \\
\hline S15 & $\alpha 1$-helix & Y165 & VL-CDR1 & H-bond \\
\hline S17 & Before $\beta 1$-strand & Y102 & VL-CDR3 & H-bond \\
\hline D18 & Before $\beta 1$-strand & R103 & VH-CDR3 & Water bridge \\
\hline T19 & $\beta 1$-strand & Y102 & VH-CDR3 & $\mathrm{CH}-\pi$ \\
\hline T19 & $\beta 1$-strand & R103 & VH-CDR3 & Van de Waals \\
\hline $\mathrm{F} 20$ & $\beta 1$-strand & R103 & VH-CDR3 & $\mathrm{CH}-\pi$ \\
\hline D39 & Before $\beta 3$-strand & Y182 & VL-FR2 & Water bridge \\
\hline D39 & Before $\beta 3$-strand & P189 & VL-CDR2 & Van de Waals \\
\hline N65 & $\beta 4$-strand & Y102 & VH-CDR3 & $\mathrm{OH}-\pi$ \\
\hline R68 & $\beta 4$-strand & Y182 & VL-FR2 & $\mathrm{H}$ bond \\
\hline $\mathrm{R} 68$ & $\beta 4$-strand & N186 & VL-CDR2 & Van de Waals \\
\hline K71 & $\beta 4$-strand & S185 & VL-CDR2 & Van de Waals \\
\hline K71 & $\beta 4$-strand & N186 & VL-CDR2 & Van de Waals \\
\hline S72 & $\beta 4$-strand & N186 & VL-CDR2 & $\mathrm{H}$ bond \\
\hline $\mathrm{H} 74$ & $\beta 4$-strand & F193 & VL-FR3 & $\pi$-stacking \\
\hline Y80 & B5-strand & Y182 & VL-FR2 & $\pi$-stacking \\
\hline Y80 & B5-strand & N186 & VL-CDR2 & Van de Waals \\
\hline Y80 & B5-strand & V187 & VL-CDR2 & $\mathrm{H}$ bond \\
\hline Y80 & B5-strand & F193 & VL-FR3 & $\pi$-stacking \\
\hline K114 & Before $\beta 8$-strand & S57 & VH-CDR2 & Van de Waals \\
\hline K114 & Before $\beta 8$-strand & $\mathrm{T} 58$ & VH-CDR2 & $\mathrm{H}$ bond \\
\hline $\mathrm{K} 114$ & Before $\beta 8$-strand & E59 & VH-CDR2 & Salt bridge \\
\hline Y115 & Before $\beta 8$-strand & W50 & VH-CDR2 & $\pi$-stacking \\
\hline Y115 & Before $\beta 8$-strand & F52 & VH-CDR2 & $\pi$-stacking \\
\hline Y115 & Before $\beta 8$-strand & Y101 & VH-CDR3 & H-bond \\
\hline P117 & Before $\beta 8$-strand & F52 & VH-CDR2 & $\mathrm{CH}-\pi$ \\
\hline P117 & Before $\beta 8$-strand & Y101 & VH-CDR3 & $\mathrm{CH}-\pi$ \\
\hline P117 & Before $\beta 8$-strand & Y102 & VH-CDR3 & $\mathrm{CH}-\pi$ \\
\hline K118 & $\beta 8$-strand & S31 & VH-CDR1 & $\mathrm{H}$ bond \\
\hline K118 & $\beta 8$-strand & E55 & VH-CDR2 & $\mathrm{H}$ bond \\
\hline K118 & $\beta 8$-strand & Y102 & VH-CDR3 & $\mathrm{H}$ bond \\
\hline F119 & $\beta 8$-strand & Y102 & VH-CDR3 & $\pi$-stacking \\
\hline E132 & $\alpha 2$-helix & Y101 & VH-CDR3 & $\mathrm{OH}-\pi$ \\
\hline E132 & $\alpha 2$-helix & Y102 & VH-CDR3 & $\mathrm{CH}-\pi$ \\
\hline E132 & $\alpha 2$-helix & R104 & VH-CDR3 & Salt bridge \\
\hline H135 & $\alpha 2$-helix & R104 & VH-CDR3 & $\mathrm{NH}-\pi$ \\
\hline H135 & $\alpha 2$-helix & W224 & VL-CDR3 & $\pi$-stacking \\
\hline Q139 & $\alpha 2$-helix & W224 & VL-CDR3 & $\mathrm{CH}-\pi$ \\
\hline Q139 & $\alpha 2$-helix & Y227 & VL-CDR3 & $\mathrm{CH}-\pi$ \\
\hline Q139 & $\alpha 2$-helix & Y229 & VL-CDR3 & $\mathrm{H}$ bond \\
\hline $\mathrm{I} 140$ & $\alpha 2$-helix & Y227 & VL-CDR3 & $\mathrm{CH}-\pi$ \\
\hline R145 & Before $\beta 9$-strand & S225 & VL-CDR3 & H-bond \\
\hline
\end{tabular}

\subsection{Inhibition of TSST-1 Activities by HuscFvs}

Experiments were performed to verify the computerized intermolecular docking results. TSST-1-mediated 7.8\% T cell activation (Figure 4). After treatment with HuscFv35, HuscFv53, and 
HuscFv56, percent activated $\mathrm{T}$ cells were reduced to $1.2 \%, 1.7 \%$, and $0.9 \%$, respectively (Figure 4 ). The inhibitory activities of the HuscFv35 and HuscFv56 were higher than the HuscFv53 which conformed to the computerized prediction that the former interacted with several TSST-1 residues important for superantigenicity. The HuscFvs did not cause percent $\mathrm{CD}^{+} 9^{+}$cell reduction among the PHA-exposed-CD3 ${ }^{+}$cells, indicating their target specificity. Control HuscFv showed modest inhibitory (placebo) effect on the percent $\mathrm{CD}^{+} 9^{+}$cells (6.5\%). Normal PBMCs contained $0.2 \% \mathrm{CD}^{+} \mathrm{CD} 69^{+}$cells.
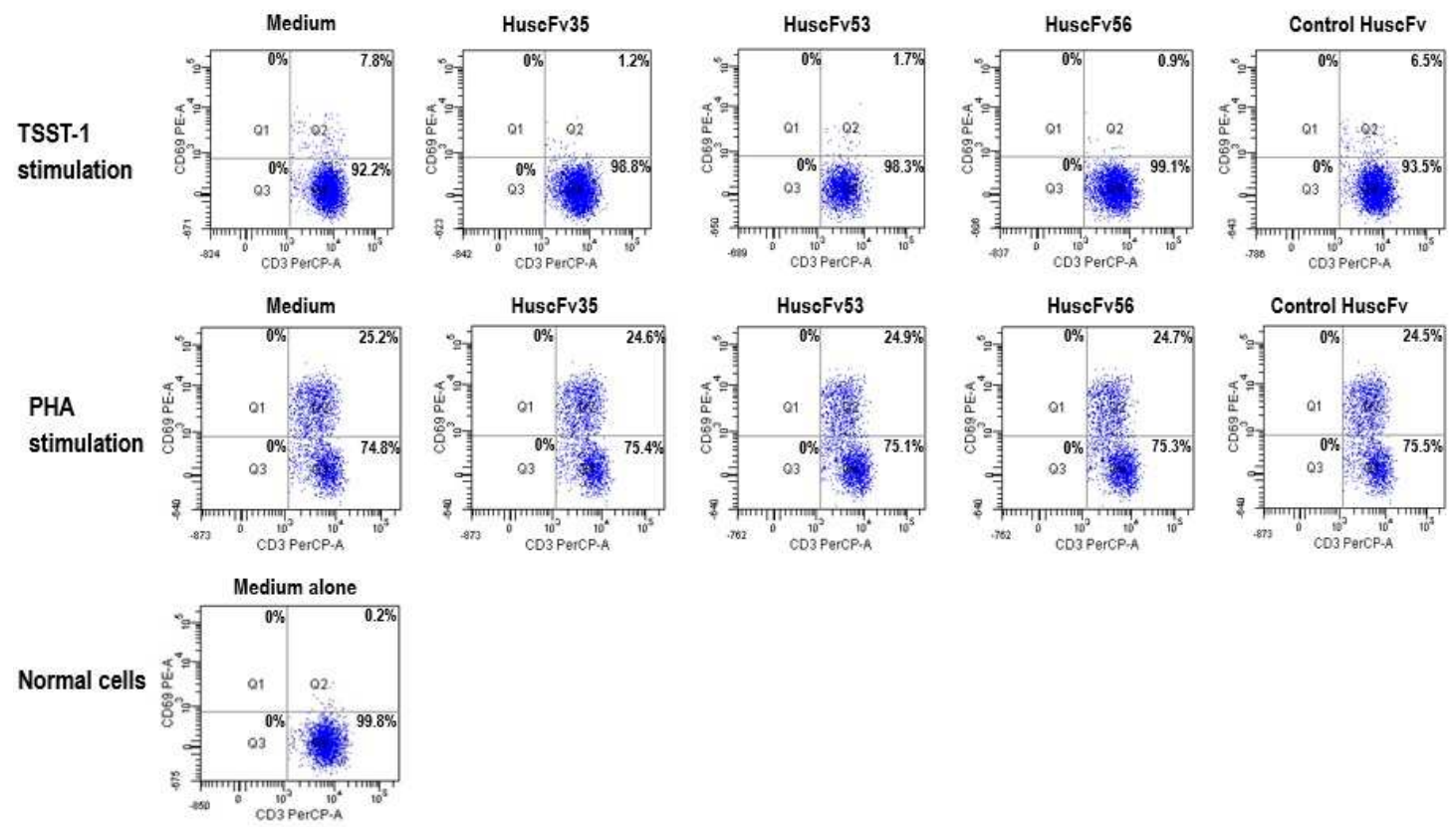

Figure 4. Percent activated $\mathrm{CD} 3^{+} \mathrm{CD} 9^{+}$among the $\mathrm{CD}^{+}$cells exposed to TSST-1 $(1000 \mathrm{ng} / \mathrm{mL})$ after treatment with individual HuscFvs $(4 \mu \mathrm{g})$, control HuscFv $(4 \mu \mathrm{g})$, and medium for $24 \mathrm{~h}$. The percent TSST-1-activated T cells (7.8\%) was markedly reduced after exposure to HuscFv35 (1.2\%), HuscFv53 $(1.7 \%)$, and HuscFv56 (0.9\%). The control HuscFv had some inhibitory activity (placebo effect) on the TSST-1-activated cells (6.5\%). The TSST-1-specific-HuscFvs did not affect the PHA-stimulated cells indicating their target specificity.

TSST-1-exposed-human PBMCs added with the HuscFvs had markedly reduced cytokine gene expressions (Figure 5) and the respective cytokine levels (Figure 6), compared to the control HuscFv-treated and non-treated cells $(p<0.05)$. Both HuscFv35 and HuscFv56 performed better than the HuscFv53. Noantibodies had an effect on the PHA-exposed cells, indicating that the HuscFv inhibitory effect on the TSST-1 pyrogenicity was target specific. The data obtained from PBMCs exposed to rTSST-1 and PHA of Figure 5 do not fit with the data of Figure 3 . The reason should be that the experiments were performed on blood samples taken a few months apart, although from the same blood donor. However data of duplicate experiments performed on blood samples taken from the blood donor one or two days apart were not statistically different, as shown by the small error bars of both Figures.

Tables 2-4 provide information on the amino acids, their positions, CDRs, and domains of the scFvs that have been predicted to involve in target binding. In order to demonstrate the relevance of the predicted HuscFv residues that formed interface contact with the TSST-1, many of the HuscFv residues which their side chains interacted with TSST-1 were substituted by alanines (marked red in Tables 2-4). The mutated residues for HuscFv35 were Y27A of VH-FR1; D31A of VH-CDR1; H100A, Q101A, and D108A of VH-CDR3; T165, N166A and Y168A of VL-CDR1; Y185A of VL-FR2; and T192A of VL-FR3; for HuscFv53 were R31A of VH-CDR1; T52A and D57A of VH-CDR2; Y168A of VL-CDR1; and K186 of VL-CDR2; and for HuscFv56 were S31A of VH-CDR1; E55A and E59A of 
VH-CDR2; Y101A, Y102A, and R104 of VH-CDR3; Y165A of VL-CDR1; Y182 of VL-FR2; N186 of VL-CDR2; and S225 and Y229 of VL-CDR3. The inhibitory activities of the wild type HuscFvs on the TSST-1-mediated cell proliferation and pro-inflammatory cytokine production were abrogated after the residue mutations, i.e., the $\mathrm{mHuscFvs}$ could not reduce mitogenicity and pyrogenicity of the TSST-1, as shown in Figures 6 and 7, respectively.

Antibodies of heterologous source have been shown to mitigate symptom severity and rescued animals from the TSS-mediated lethality [30,31]. Treatment of human TSS cases is usually performed in the intensive care unit and includes supportive and symptomatic measures, removal of bacteria producing the causative toxin as well as infusion of IVIG thought to contain antibodies to bacterial endotoxin. However, passive immunization and immunotherapy by using homologous (human) antibodies directed to the TSST-1 functionally critical residues has never been performed. Human scFvshave potential applications for immunotherapy of diseases [38-40]. Thus, the fully human scFvs produced in this study, especially the HuscFv35 and HuscFv56 have high potential for testing further as a safe, direct acting anti-TSST-1 remedy.

\section{$I L-1 \beta$}

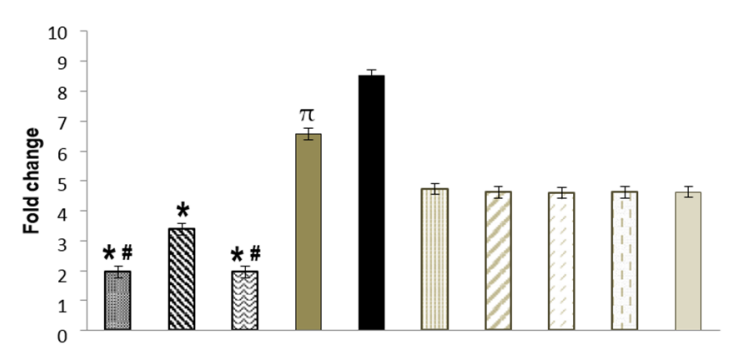

IL-6
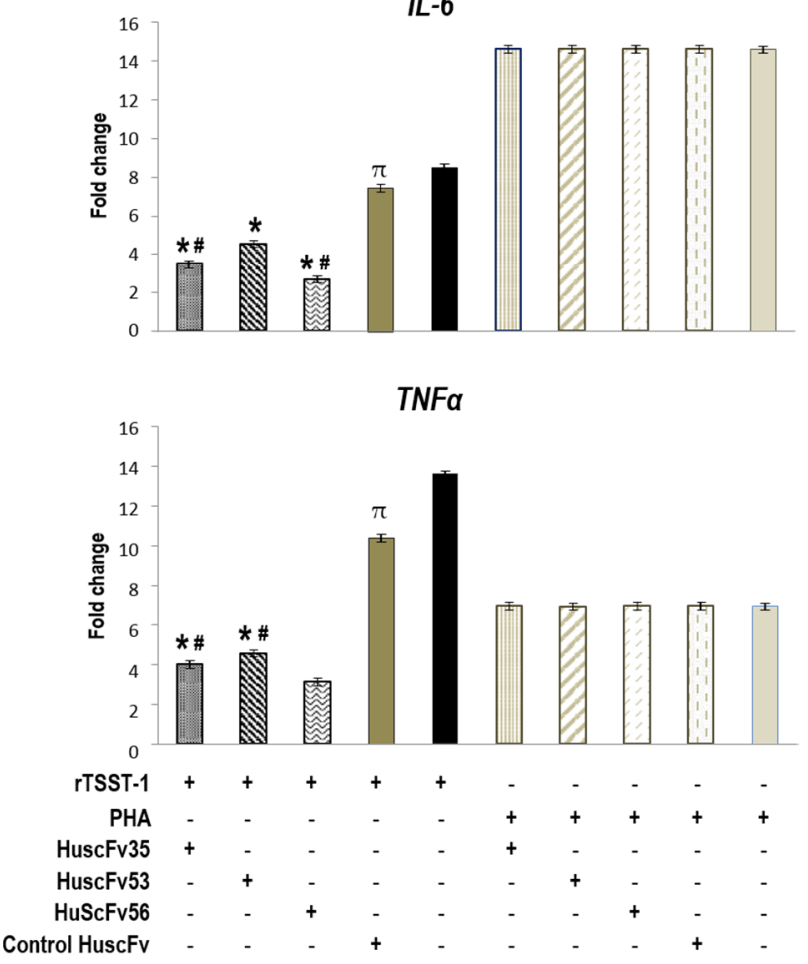

Figure 5. Fold change of IL-1 $\beta$, IL-6, and TNF $\alpha$ gene expressions in human PBMCs that had been exposed to $1000 \mathrm{ng} / \mathrm{mLof}$ TSST-1 and treated with $4 \mu$ gof HuscFv35, HuscFv53, and HuscFv56 and controls for $24 \mathrm{~h} .{ }^{*}$, significantly different from (lower than) both controls $(p<0.05)$; \#, significantly different from HuscFv53-treated, TSST-1-exposed cells $(p<0.05) ; \pi$, significantly different from TSST-1-exposed cells in medium alone, indicating a placebo effect of the control HuscFv. 



TNFa

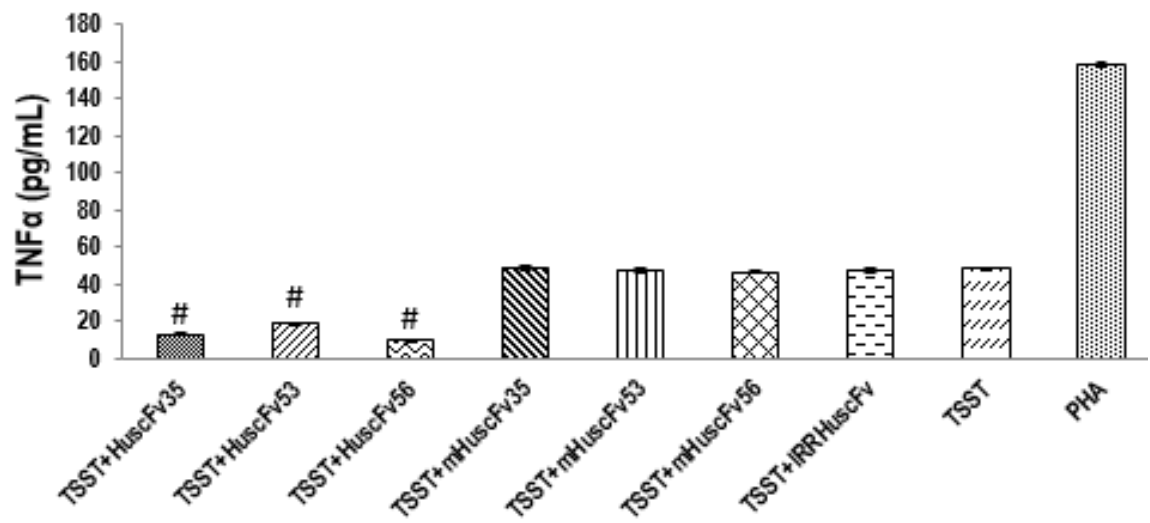

Figure 6. Levels of IL-1 $\beta$, IL-6, and TNF $\alpha$ cytokines in culture supernatants of PBMCs exposed to $1000 \mathrm{ng} / \mathrm{mL}$ of rTSST-1after treatment with $4 \mu \mathrm{g}$ of TSST-1-bound-HuscFvs, $4 \mu \mathrm{g}$ CDR mutated-HuscFvs, negative control (TSST-1-exposed cells in medium alone), and positive control (cells stimulated with $1000 \mathrm{ng} / \mathrm{mL}$ PHA). \#, significantly lower than the groups treated with mHuscFvs and TSST-1- and PHA-stimulated cells. 



HuscFv35
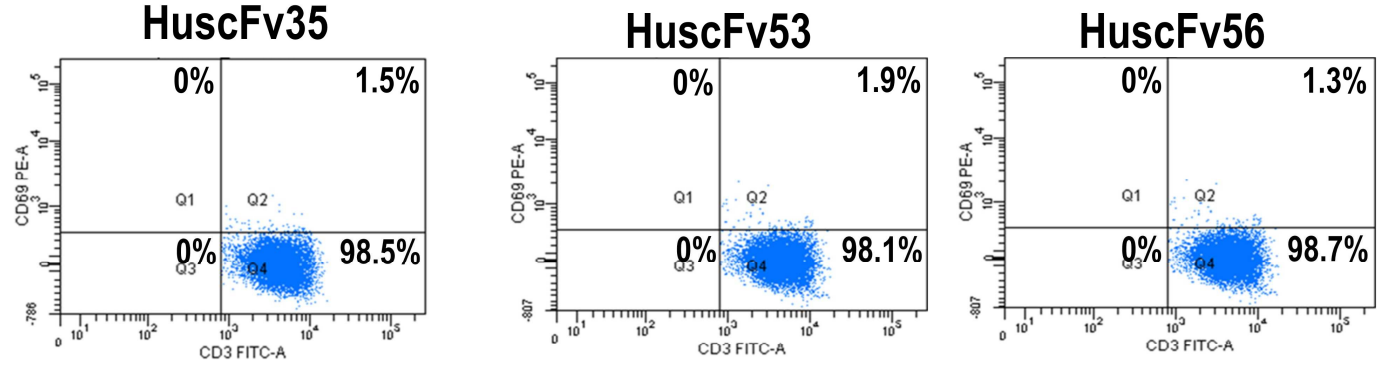

mHuscFv35

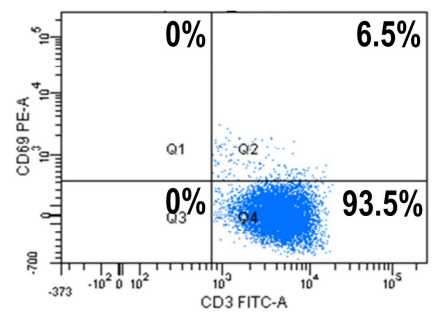

mHuscFv53


Figure 7. Percent activated T cells $\left(\mathrm{CD}^{+} \mathrm{CD}^{+} 9^{+}\right)$among the TSST-1-exposed PBMCs after treatment with HuscFv35, HuscFv53, and HuscFv56, mutated-HuscFvs (mHuscFv35, mHuscFv53, and mHuscFv56), control HuscFv, and medium. The mutated-HuscFvs could not reduce TSST-1 mitogenicity on the human PBMCs (percent activated T cells were not different from the TSST-1-exposed PBMCs cultured in the medium alone).

\section{Materials and Methods}

\subsection{Recombinant TSST-1 (rTSST-1) Production}

TSST-1 gene was retrieved from GenBank no. J02615. Synthetic TSST-1 gene sequence with stop codondeletion and BamH1 and HindIII restriction sites incorporation at the $5^{\prime}$ and $3^{\prime}$ ends, respectively, was inserted into pET21a ${ }^{+}$DNA (GenScript). The recombinant plasmid was used to transform NiCo21 (DE3) E. coli by means of a highly efficient transformation protocol (New England Biolabs, UK). Appropriately transformed E. coli colony was grown in LB-A broth containing $1 \mathrm{mM} \mathrm{IPTG}$ and the $6 \times$ His-tagged-rTSST-1 was purified from the bacterial lysate by using Ni-NTA resin (Invitrogen, Waltham, MA, USA).

\subsection{Mitogenic and Pyrogenic Activities of rTSST-1}

Because activated T cells expressed surface CD69 molecules [41]; thus, mitogenicity testing of the rTSST- 1 was performed by detecting percentages of $\mathrm{CD} 3^{+} \mathrm{CD} 69^{+}$in human PBMCs after exposure to the toxin and controls. Human PBMCs $\left(3 \times 10^{5}\right.$ cells $/$ well) were cultured in 48 -well round-bottom tissue culture plate (Corning) in RPMI-1640 medium $\left(\mathrm{Gibco}^{\mathrm{TM}}\right)$ supplemented with $10 \%$ fetal bovine serum, $2 \mathrm{mM}$ L-glutamine, 100 units $/ \mathrm{mL}$ penicillin, and $100 \mu \mathrm{g} / \mathrm{mL}$ streptomycin (complete medium) at $37^{\circ} \mathrm{C}$ in $5 \% \mathrm{CO}_{2}$ atmosphere. Various concentrations of rTSST-1 $(10-1000 \mathrm{ng} / \mathrm{mL})$ were added appropriately to the cells. Positive control was cells stimulated with $1000 \mathrm{ng} / \mathrm{mL}$ phytohemagglutinin (PHA) (Sigma) 
which is a pan T cell mitogen and negative control was cells in culture medium alone. After $24 \mathrm{~h}$, cells were washed twice with cell washing/blocking reagent (1\% heat-inactivated normal serum in PBS), re-suspended in fresh culture medium, added with anti-CD3-PerCP and anti-CD69-PE, and subjected to FACScan flow cytometry with BD Diva software for data acquisition and analysis. Lymphocyte population was identified using forward and side scattered property. T cell population was identified by cells that were $\mathrm{CD}^{+}$. The percentage of activated $\mathrm{T}$ cells $\left(\mathrm{CD}^{+}{ }^{+} \mathrm{CD} 69^{+}\right)$was determined from an upper-right quadrant $(\mathrm{Q} 2)$ where as $\mathrm{Q} 4$ was $\mathrm{CD}^{+}$cells. The $\mathrm{Q} 1$ and $\mathrm{Q} 3$ were non-activated cell population $\left(\mathrm{CD}^{-} \mathrm{CD}^{-} 9^{-}\right)$. Results are expressed as percentages of $\mathrm{CD}^{+} \mathrm{CD} 69^{+}$cells.

For testing rTSST-1-mediated cell proliferation, human PBMCs were incubated with violet CellTrace $^{\mathrm{TM}}$ for $20 \mathrm{~min}$ in complete medium before stimulating with rTSST-1 as above. Similar controls were included. After $72 \mathrm{~h}$, cells were washed, stained with anti-CD3-PerCP, and subjecting to FACScan flow cytometry. Results were expressed as percentages of violet/pacific blue stained-CD3 ${ }^{+}$cells.

Pyrogenicity of rTSST- 1 was tested. Human PBMCs $\left(1 \times 10^{5}\right.$ cells/well $)$ were cultured and stimulated with various concentrations of rTSST- 1 as above. Similar controls were included. After $24 \mathrm{~h}$, total RNAs were extracted from cells in individual wells. Expressions of pro-inflammatory cytokine genes including $I L-1 \beta, I L-6$, and TNF $\alpha$ were determined by quantitative real-time RT-PCR (qRT-PCR) using primers listed in Table S2. One microliter cDNA(50 ng) and $100 \mathrm{nM}$ each PCR primer was put in SYBR Green Master Mix (Applied Biosystems) and subjected to PCR reaction: $95^{\circ} \mathrm{C}, 10 \mathrm{~min}$ then 36 cycles of denaturation at $95{ }^{\circ} \mathrm{C}$ for $30 \mathrm{~s}$, annealing at $60{ }^{\circ} \mathrm{C}$ for $1 \mathrm{~min}$, extension at $72{ }^{\circ} \mathrm{C}$ for $30 \mathrm{~s}$, and hold at $72{ }^{\circ} \mathrm{C}$ for $5 \mathrm{~min}$ in Strategene Mx3005P QPCR System (Agilent Technologies). Data were analyzed using MxPro QPCR software. $\beta$-actin gene was used for normalization. Levels of the pro-inflammatory cytokines in cell culture supernatants were determined by using ELISA kit (Thermo Fisher Scientific, Waltham, MA, USA).

\subsection{Production of TSST-1-bound HuscFvs}

Human scFv phage display library used in this study was constructed previously [42]. Briefly, cDNAs were prepared from mRNAs of peripheral blood lymphocytes of multiple human blood donors and used as templates for amplification of immunoglobulin VH and VK coding sequences by PCR. The oligonucleotide primers used for the PCR were human degenerate primers designed from all families of human immunoglobulin variable sequences [42]. The PCR amplified $v h$ and $v l$ sequences were ligated randomly via a polynucleotide linker (coding for $\left.\left(\mathrm{Gly}_{4} \mathrm{Ser}\right)_{3}\right)$ to generate a repertoire of vh-linker-vl sequences or $s c f v$ sequences. The scfvs were ligated with pCANTAB5E phagemid DNAs and the recombinant phagemids were used to transfect TG1 E. coli. After growing the recombinant phagemid-transformed E. coli in the presence of helper phage (M13KO7), complete phage particles which displayed human scFvs as fusion proteins with the phage coat protein (p3) and also carried the respective scfus in the phage genomes could be obtained from the E. coli culture supernatant.

HuscFv-displayed phage clones that bound to the rTSST-1 were fished-out from the library using the recombinant protein as bait in the biopanning process [42]. The phage library was added to an ELISA well pre-coated with $1 \mu \mathrm{g}$ of purified rTSST- 1 and the plate was incubated at $37^{\circ} \mathrm{C}$ for 1 h. Unbound phages were removed by washing with buffer and a log phase-grown HB2151 E. coli culture was added to the well containing the antigen-bound phages.The phage transformed bacterial coloniesthat grew on selective agar plates after overnight incubation were screened for the HuscFv genes (huscfos) by PCR [42]. The huscfv-positive clones were grown in $0.2 \mathrm{mMIPTG}$-conditioned broth to induce HuscFv expressions. Binding of soluble HuscFvs in the bacterial lysates to the SDS-PAGE-separated-rTSST-1 were tested by Western blotting. Nucleotides of the huscfos coding for rTSST-1-bound-HuscFvs were sequenced, deduced, and canonical complementarity determining regions (CDRs) and immunoglobulin framework regions (FRs) were determined using the IMGT $^{\circledR}$ Information System [43].

For large scale production of HuscFvs, huscfus of HB2151 E. coli clones of interest were subcloned from the phagemids to pLATE52 ${ }^{\mathrm{TM}}$ expression vector by using ligation independent cloning (LIC) 
system (Thermo Fisher Scientific). The pLATE52-huscfo plasmids were used to transfect NiCo21 (DE3) E. coli. Selected transformed bacterial colonies were grown under IPTG induction; the bacterial pellet was suspended in BugBuster ${ }^{\circledR}$ Protein Extraction buffer $(5 \mathrm{~mL} / \mathrm{g}$ bacterial wet weight) and kept at $25{ }^{\circ} \mathrm{C}$ with agitation. The preparation was added with Lysonase ${ }^{\mathrm{TM}}$ Bioprocessing reagent $(10 \mu \mathrm{L} / \mathrm{g}$ of bacteria) and agitated further for $20 \mathrm{~min}$. E. coli inclusion body was harvested by centrifugation, washed twice with Wash-100 Solution (50 mM sodium phosphate buffer, $\mathrm{pH} 8.0 ; 500 \mathrm{mM} \mathrm{NaCl}$; $5 \mathrm{mM}$ EDTA; $8 \%(w / v)$ glycerol; $1 \%(v / v)$ TritonX-100); twice with Wash-114 Reagent (50 mM Tris buffer, $\mathrm{pH} 8.0 ; 300 \mathrm{mM} \mathrm{NaCl} ; 1 \%(v / v)$ Triton X-114), and once with Wash-Solvent (50 mM Tris buffer, $\mathrm{pH} 8.0 ; 60 \%(v / v)$ isopropanol) by shaking the preparation vigorously followed by centrifugation. For HuscFv refolding, the inclusion body was solubilized $(w / v)$ in buffer (50 mM CAPS, pH 11.0; 0.3\% $(w / v)$ N-lauryl sarcosine; $1 \mathrm{mM}$ DTT) and kept at $4{ }^{\circ} \mathrm{C}$ for $16 \mathrm{~h}$. The preparation was loaded into the Slide-A-Lyzer ${ }^{\circledR} 2 \mathrm{~K}$ Dialysis Cassettes G2 (Thermo Fisher Scientific), dialyzed at $4{ }^{\circ} \mathrm{C}$ with slow stirring against refolding buffer ( $20 \mathrm{mM}$ imidazole, $\mathrm{pH} 8.5$ supplemented with $0.1 \mathrm{mM} \mathrm{DTT}$ ), filtered through $0.02 \mu \mathrm{m}$ low protein binding Acrodisc ${ }^{\circledR}$ syringe filter (Pall, Port Washington, NY, USA), and kept in water-bath at $30{ }^{\circ} \mathrm{C}$ for $2 \mathrm{~h}$ before adding with $60 \mathrm{mM}$ trehalose. Protein content was determined. The refolded-HuscFvs were retested for binding to rTSST-1 by indirect ELISA.

\subsection{Computerized Simulation for Determining Interactive Residues between TSST-1 and HuscFvs}

TSST-1 3D structure was retrieved from RCSB PDB 2IJO. The huscfo 3D structures were modeled by the I-TASSER server [44,45]. The I-TASSER-predicted structures were further refined $[46,47]$ and improved to near native states on the automated ClusPro 2.0 antibody-protein docking server. The models from the docking were simulated with NAMD Molecular Dynamics [48]. The TSST-1-HuscFv complexes were built and visualized by using PyMol software (PyMol Molecular Graphics System, Version 2 edu, Schrodinger, LLC).

\subsection{Preparation of Mutated-HuscFvs ( $m H u s c F v s$ )}

Gene sequences coding for HuscFvs which side chains of their residues interacted with TSST-1 (data from molecular dynamics) were substituted by alanines and synthesized (Integrated DNA Technologies, Coralville, IA, USA). The DNA fragments were cloned into pLATE52 and the recombinant vector was used to transform NiCo21 (DE3) E. coli. The HuscFvs were prepared from appropriately transformed E. coli as for the wild type HuscFvs. The mutated HuscFvs (mHuscFvs) were tested for their ability to inhibit TSST-1 activities (mitogenicity and pyrogenicity).

\subsection{HuscFvs-mediated Inhibition of TSST-1 Activities}

For inhibition of TSST-1-mediated T cell activation by the HuscFvs, human PBMCs were added with mixture of rTSST-1 and HuscFvs/mHuscFvs or control HuscFv and kept for $24 \mathrm{~h}$. TSST-1-stimulated cells without antibody treatment, PHA-stimulated cells treated similarly with TSSTS-1-bound-HuscFvs, and normal cells in medium were included in the experiment. After washing, cells were labeled with CD3-PerCP and CD69-PE and analyzed by FACScan Flow cytometry. Total viable lymphocytes were gated by SSC and FSC and $\mathrm{CD}^{+}$cells were gated for $\mathrm{CD}^{+} 9^{+}$cells. Results were expressed as percentages of $\mathrm{CD}^{+} \mathrm{CD} 9^{+}$cells.

For inhibiting rTSST-1 pyrogenicity by the HuscFvs $/ \mathrm{mHuscFv}$, human PBMCs $\left(5 \times 10^{4}\right.$ cells $/$ well $)$ in complete medium were added with $1000 \mathrm{ng} / \mathrm{mL}$ rTSST-1. The TSST-1-stimulated cells were treated either with TSST-1-bound-HuscFvs/mHuscFv, control/irrelevant HuscFv (did not bind to TSST-1), or medium alone. The antibody:TSST-1 molar ratios were 4:1 (optimal from titration). Triplicate wells were set for each treatment. Cells added with $1000 \mathrm{ng} / \mathrm{mL}$ PHA with and without HuscFv-treatments, and cells in medium alone (normal cells) were included. After $24 \mathrm{~h}$, total RNAs were extracted from cells in individual wells and quantified by using NanoDrop instrument. Complementary DNAs were synthesized (RevertAid First Strand cDNA Synthesis kit) and used as templates for quantification of mRNAs of pro-inflammatory cytokines including TNF- $\alpha$, IL-1B, and IL-6. The quantitative 
real-time PCR primers for the mRNA quantification are listed in Table S2. $\beta$-actin gene was used for normalization. Moreover, cell culture supernatants in all wells were collected and the levels of the pro-inflammatory cytokines were measured using commercial ELISA kits (Thermo Fisher Scientific). Results are the average of the two reproducible experiments.

\subsection{Statistical Analysis}

One way ANOVA followed by post hoc comparison using least significant difference (LSD) and independent $t$-test were performed for data comparison using SPSS 18.0 statistical software. Significant difference was $p<0.05$.

\section{Conclusions}

Human single chain antibodies (HuscFvs) to S. aureus TSST-1 that inhibited the TSST-1-mediated $\mathrm{T}$ cell activation and pro-inflammatory cytokine gene expressions and productions were generated. The HuscFvs formed interface contact with the TSST-1 residues important for immunopathogenesis of toxic shock syndrome. The HuscFvs have high potential for testing further as a direct acting anti-TSST-1 agent for future clinical use.

Supplementary Materials: The following are available online at www.mdpi.com/2072-6651/9/2/50/s1, Figure S1: Codon-optimized nucleotide and deduced amino acid sequences of the TSST-1 of this study. Figure S2: Effect of lipopolysaccharide (LPS) on PBMC stimulation compared to TSST-1. Figure S3: Binding of the purified, refolded HuscFv35 (T35), HuscFv53 (T53) and HuscFv56 (T56) to rTSSt-1 and SEA immobilized on the ELISA well surface with and without BSA. Figure S4: Computerized bindingof TSST-1 (cyan) and HuscFvs (green). Figure S5: Residues and motives of TSST-1. Table S1: Estimated accuracy of the modeled HuscFv35, HuscFv53, and HuscFv56. Table S2: Oligonucleotide primers used in quantitative real-time RT-PCR for monitoring cytokine gene expressions.

Acknowledgments: The work was supported by NSTDA Chair professor grant (P-1450624) funded by the Crown Property Bureau of Thailand, RSA5980048 of the Thailand Research Fund (TRF) and the NRU Project, Office of Commission on Higher Education. Nitaya Indrawattana and Nitat Sookrung are RSA scholars of the TRF.

Author Contributions: N.S., W.C. and N.I. conceived and designed the experiments. T.R. and W.S. performed the experiments. N.O., P.D., N.S., W.C. and N.I. analyzed the data. W.C. and N.I. reviewed and wrote the manuscript.

Conflicts of Interest: The authors declare no conflict of interest.

\section{References}

1. Kotb, M. Bacterial pyrogenic exotoxins as superantigens. Clin. Microbiol. Rev. 1995, 8, 411-426. [PubMed]

2. Todd, J.; Fishaut, M.; Kapral, F.; Welch, T. Toxic-shock syndrome associated with phage-group-I Staphylococci. Lancet 1978, 2, 1116-1118. [CrossRef]

3. Bueno, C.; Lemke, C.D.; Criado, G.; Baroja, M.L.; Ferguson, S.S.; Rahman, A.K.; Tsoukas, C.D.; McCormick, J.K.; Madrenas, J. Bacterial superantigens bypass Lck-dependent $\mathrm{T}$ cell receptor signaling by activating a G $\alpha 11$-dependent, PLC- $\beta$-mediated pathway. Immunity 2006, 25, 67-78. [CrossRef] [PubMed]

4. Tofte, R.W.; Williams, D.N. Toxic shock syndrome: Clinical and laboratory features in 15 patients. Ann. Intern. Med. 1981, 94, 149-156. [CrossRef] [PubMed]

5. Priest, B.P.; Schlievert, P.M.; Dunn, D.L. Treatment of toxic shock syndrome with endotoxin-neutralizing antibody. J. Surg. Res. 1989, 46, 527-531. [CrossRef]

6. Kulhankova, K.; King, J.; Salgado-Pabón, W. Staphylococcal toxic shock syndrome: Superantigen-mediated enhancement of endotoxin shock and adaptive immune suppression. Immunol. Rev. 2014, 59, 182-187. [CrossRef] [PubMed]

7. Proft, T.; Frazer, J.D. Bacterial superantigens. Clin. Exp. Immunol. 2003, 133, 299-306. [CrossRef] [PubMed]

8. Kass, E.H.; Parsonnet, J. On the pathogenesis of toxic shock syndrome. Rev. Infect. Dis. 1987, 9, S482-S489. [CrossRef] [PubMed]

9. Shands, K.N.; Schmid, G.P.; Dan, B.B.; Blum, D.; Guidotti, R.J.; Hargrett, N.T.; Anderson, R.L.; Hill, D.L.; Broome, C.V.; Band, J.D.; et al. Toxic shock syndrome in menstruating women: Association with tampon use and Staphylococcus aureus and clinical features in 52 cases. N. Engl. J. Med. 1980, 303, 1438-1442. [CrossRef] [PubMed] 
10. Kim, J.; Urban, R.G.; Strominger, J.L.; Wiley, D.C. Toxic shock syndrome toxin-1 complexed with a class II major histocompatibility molecules HLA-DR1. Science 1994, 266, 1870-1874. [CrossRef] [PubMed]

11. Petersson, K.; Håkansson, M.; Nilsson, H.; Forsberg, G.; Anders Svensson, L.; Liljas, A.; Walse, B. Crystal structure of a superantigen bound to MHC class II displays zinc and peptide dependence. EMBO J. 2001, 20, 3306-3312. [CrossRef] [PubMed]

12. Li, H.; Llera, A.; Tsuchiya, D.; Leder, L.; Ysern, X.; Schlievert, P.M.; Karjalalnen, K.; Mariuzza, R.A. Three dimensional structure of the complex between a $\mathrm{T}$ cell receptor beta chain and the superantigen staphylococcal enterotoxin B. Immunity 1998, 9, 807-816. [CrossRef]

13. Li, H.; Llera, A.; Malchiodi, E.L.; Mariuzza, R.A. The structural basis of $\mathrm{T}$ cell activation by superantigens. Annu. Rev. Imunol. 1999, 17, 435-466. [CrossRef] [PubMed]

14. Günther, S.; Varma, A.K.; Moza, B.; Kasper, K.J.; Wyatt, A.W.; Zhu, P.; Nur-urRahman, A.K.M.; Li, Y.; Mariuzza, R.A.; McCormick, J.K.; et al. A novel loop domain in superantigens extends their T cell receptor recognition site. J. Mol. Biol. 2007, 371, 210-221. [CrossRef] [PubMed]

15. Murray, D.L.; Earhart, C.A.; Mitchell, D.T.; Ohlendorf, D.H.; Norvick, R.P.; Schlievert, P.M. Localization of biologically important regions on toxic shock syndrome toxin 1. Infect. Immun. 1996, 64, 371-374. [PubMed]

16. McCormick, J.K.; Yarwood, J.M.; Schlievert, P.M. Toxic shock syndrome and bacterial superantigens: An update. Annu. Rev. Mocrobiol. 2001, 55, 77-104. [CrossRef] [PubMed]

17. Lindsay, J.A.; Ruzin, A.; Ross, H.F.; Kurepina, N.; Novick, R.P. The gene for toxic shock toxin is carried by a family of mobile pathogenicity islands in Staphylococcus aureus. Mol. Microbiol. 1998, 29, 527-543. [CrossRef] [PubMed]

18. Acharya, K.R.; Passalacqua, E.F.; Jones, F.Y.; Harlos, K.; Stuart, D.I.; Brehm, R.D.; Tranter, H.S. Structural basis of superantigen action inferred from crystal structure of toxic shock syndrome toxin-1. Nature 1994, 367, 94-97. [CrossRef] [PubMed]

19. Prasad, G.S.; Radhakrishnan, R.; Mitchell, D.T.; Earhart, C.A.; Dinges, M.M.; Cook, W.J.; Schlievert, P.M.; Ohlendorf, D.H. Refined structures of three crystal forms of toxic shock syndrome toxin-1 and of a tetramutant with reduced activity. Prot. Sci. 1997, 6, 1220-1227. [CrossRef] [PubMed]

20. Jardetzky, T.S.; Brown, J.H.; Gorga, J.C.; Stern, L.J.; Urban, R.G.; Chi, Y.I.; Stauffacher, C.; Strominger, J.L.; Wiley, D.C. Three dimensional structure of a human class II histocompatibility molecule complexed with superantigen. Nature 1994, 368, 711-718. [CrossRef] [PubMed]

21. Wahlsten, J.L.; Ramakrishnan, S. Separation of function between the domains of toxic shock syndrome toxin-1. J. Immunol. 1998, 160, 854-859. [PubMed]

22. Wu, C.C. Possible therapies of septic shock: Based on animal studies and clinical trials. Curr. Pharm. Des. 2006, 27, 3535-3541. [CrossRef]

23. Mellish, M.E.; Cherry, J.D. Staphylococcal infections. In Pediatric Infectious Diseases; Feigin, R.D., Ed.; WB Saunders and Company: Philadelphia, PA, USA, 1992.

24. Shankar-Hari, M.; Spencer, J.; Sewell, W.A.; Rowan, K.M.; Singer, M. Bench-to-bedside review: Immunoglobulin therapy for sepsis-biological plausibility from a critical perspective. Crit. Care 2002, 16, 206-220. [CrossRef] [PubMed]

25. Bonventre, P.F.; Thompson, M.R.; Adinolfi, L.E.; Gillis, Z.A.; Parsonnet, J. Neutralization of toxic shock syndrome toxin-1 by monoclonal antibodies in vitro and in vivo. Infect. Immun. 1988, 56, 135-141. [PubMed]

26. Stich, N.; Model, N.; Samstag, A.; Gruener, C.S.; Wolf, H.M.; Eibl, M.M. Toxic shock syndrome toxin-1 mediated toxicity inhibited by neutralizing antibodies late in the course of continual in vivo and in vitro exposure. Toxins 2014, 6, 1724-1741. [CrossRef] [PubMed]

27. Ryan, J. Endotoxin and Cell Culture Technical Bulletin; Corning Incorporated Life-Science: Lowell, MA, USA, 2008.

28. Stich, N.; Waclavicek, M.; Model, N.; Eibl, M.M. Staphylococcal superantigen (TSST-1) mutant analysis reveals that $\mathrm{T}$ cell activation is required for biological effect in the rabbit including the cytokine storm. Toxins 2010, 2, 2272-2288. [CrossRef] [PubMed]

29. Zhou, Y.H.; Chen, Z.; Purcell, RH.; Emerson, S.U. Positive reactions on Western blots do not necessarily indicate the epitopes on antigens are continuous. Immunol. Cell Biol. 2007, 85, 73-78. [CrossRef] [PubMed]

30. Gampfer, J.M.; Samstag, A.; Waclavicek, M.; Wolf, H.M.; Eibl, M.M.; Gulle, H. Epitope mapping of neutralizing TSST-1 specific antibodies induced by immunization with toxin and toxoid. Vaccine 2002, 20, 3675-3684. [CrossRef] 
31. Papageorgiou, A.C.; Brehm, R.D.; Leonidas, D.D.; Tranter, H.S.; Acharya, K.R. The refined crystal structure of toxic shock syndrome toxin-1 at 2.07 A resolution. J. Mol. Biol. 1996, 260, 553-569. [CrossRef] [PubMed]

32. Earhart, C.A.; Mitchell, D.T.; Murray, D.L.; Pinheiro, D.M.; Matsumura, M.; Schlievert, P.M.; Ohlendorf, D.H. Structures of five mutants of toxic shock syndrome toxin-1 with reduced biological activity. Biochemistry 1998, 37, 7194-7202. [CrossRef] [PubMed]

33. Deresiewicz, R.L.; Woo, J.; Chan, M.; Finberg, R.W.; Kasper, D.L. Mutations affecting the activity of toxic shock syndrome toxin-1. Biochemistry 1994, 33, 12844-12851. [CrossRef] [PubMed]

34. Moza, B.; Buonpane, R.A.; Zhu, P.; Herfst, C.A.; Nur-urRahman, A.K.M.; McCormick, J.K.; Kranz, D.M.; Sundberg, E.J. Long-range cooperative binding effects in a T cell receptor variable domain. Proc. Natl. Acad. Sci. USA 2006, 103, 9867-9872. [CrossRef] [PubMed]

35. Bonventre, P.F.; Heeg, H.; Cullen, C.; Lian, C.J. Toxicity of recombinant toxic shock syndrome toxin 1 and mutant toxins produced by Staphyloccocus aureus in a rabbit infection model of toxic shock syndrome. Infect. Immun. 1993, 61, 793-799. [PubMed]

36. Drynda, A.; König, B.; Bonventre, P.F.; König, W. Role of a carboxy-terminal site of toxic shock syndrome toxin 1 in eliciting immune responses of human peripheral blood mononuclear cells. Infect. Immun. 1995, 63, 1095-1101. [PubMed]

37. McCormick, J.K.; Tripp, T.J.; Llera, A.S.; Sundberg, E.J.; Dinges, M.M.; Mariuzza, R.A.; Schlievert, P.M. Functional analysis of the TCR binding domain of toxic shock syndrome toxin-1 predicts further diversity in MHC class II/superantigen/TCR ternary complexes. J. Immunol. 2003, 171, 1385-1392. [CrossRef] [PubMed]

38. Ahmad, Z.A.; Yeap, S.K.; Ali, A.M.; Ho, W.Y.; Alitheen, N.B.; Hamid, M. scFv antibody: Principles and clinical application. Clin. Dev. Immunol. 2012, 2012, 980250. [CrossRef] [PubMed]

39. Pucca, M.B.; Zoccal, K.F.; Roncolato, E.C.; Bertolini, T.B.; Campos, L.B.; Cologna, C.T.; Faccioli, L.H.; Arantes, E.C.; Barbosa, J.E. Serrumab: A human monoclonal antibody that counters the biochemical and immunological effects of Tityusserrulatus venom. J. Immunotoxicol. 2012, 9, 173-183. [CrossRef] [PubMed]

40. Jittavisutthikul, S.; Seesuay, W.; Thanongsaksrikul, J.; Thueng-in, K.; Srimanote, P.; Werner, R.G.; Chaicumpa, W. Human transbodies to HCV NS3/4A protease inhibit viral replication and restore host innate immunity. Front. Immunol. 2016, 7, 318. [CrossRef] [PubMed]

41. Lina, G.; Cozon, G.; Ferrandiz, J.; Greenland, T.; Vandenesch, F.; Etienne, J. Detection of staphylococcal superantigenic toxin by a CD69-specific cytofluorimetric assay measuring T-cell activation. J. Clin. Microbiol. 1998, 36, 1042-1045. [PubMed]

42. Kulkeaw, K.; Sakolvaree, Y.; Srimanote, P.; Tongtawe, P.; Maneewatch, S.; Sookrung, N.; Tungthrongchitr, A.; Tapchaisri, P.; Kurazono, H.; Chaicumpa, W. Human monoclonal ScFv neutralize lethal Thai cobra, Najakaouthia, neurotoxin. J. Proteom. 2009, 72, 270-282. [CrossRef] [PubMed]

43. Giudicelli, V.; Brochet, X.; Lefranc, M.P. IMGT/V-QUEST: IMGT standardized analysis of the immunoglobulin (IG) and T cell receptor (TR) nucleotide sequences. Cold Spring Harb. Protoc. 2011, 2011, 695-715. [CrossRef] [PubMed]

44. Zhang, Y. I-TASSER server for protein 3D structure prediction. BMC Bioinform. 2008, 9, 40. [CrossRef] [PubMed]

45. Roy, A.; Kucukural, A.; Zhang, Y. I-TASSER: A unified platform for automated protein structure and function prediction. Nat. Protoc. 2010, 5, 725-738. [CrossRef] [PubMed]

46. Xu, D.; Zhang, Y. Improving the physical realism and structural accuracy of protein models by a two-step atomic-level energy minimization. Biophys. J. 2011, 101, 2525-2534. [CrossRef] [PubMed]

47. Zhang, J.; Liang, Y.; Zhang, Y. Atomic-level protein structure refinement using fragment-guided molecular dynamics conformation sampling. Structure 2011, 19, 1784-1795. [CrossRef] [PubMed]

48. Hospital, A.; Andrio, P.; Fenollosa, C.; Cicin-Sain, D.; Orozco, M.; Gelpí, J.L. MDWeb and MDMoby: An integrated web-based platform for molecular dynamics simulations. Bioinformatics 2012, 28, 1278-1279. [CrossRef] [PubMed]

(c) 2017 by the authors; licensee MDPI, Basel, Switzerland. This article is an open access article distributed under the terms and conditions of the Creative Commons Attribution (CC BY) license (http:/ / creativecommons.org/licenses/by/4.0/). 